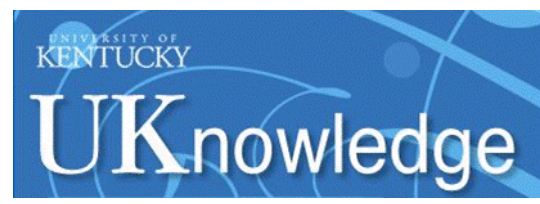

University of Kentucky

UKnowledge

Information Science Faculty Publications

Information Science

2020

\title{
Values, Risks, and Power Influencing Librarians' Decisions to Host Drag Queen Storytime
}

\author{
Diana Floegel \\ Rutgers, The State University of New Jersey \\ Sarah C. Barriage \\ University of Kentucky, sarah.barriage@uky.edu \\ Vanessa Kitzie \\ University of South Carolina \\ Shannon M. Oltmann \\ University of Kentucky, shannon.oltmann@uky.edu
}

Follow this and additional works at: https://uknowledge.uky.edu/slis_facpub

Part of the Library and Information Science Commons

Right click to open a feedback form in a new tab to let us know how this document benefits you.

\section{Repository Citation}

Floegel, Diana; Barriage, Sarah C.; Kitzie, Vanessa; and Oltmann, Shannon M., "Values, Risks, and Power Influencing Librarians' Decisions to Host Drag Queen Storytime" (2020). Information Science Faculty Publications. 97.

https://uknowledge.uky.edu/slis_facpub/97

This Conference Proceeding is brought to you for free and open access by the Information Science at UKnowledge. It has been accepted for inclusion in Information Science Faculty Publications by an authorized administrator of UKnowledge. For more information, please contact UKnowledge@lsv.uky.edu. 


\title{
Values, Risks, and Power Influencing Librarians' Decisions to Host Drag Queen Storytime
}

\author{
Digital Object Identifier (DOI) \\ https://doi.org/10.1002/pra2.212 \\ Notes/Citation Information
}

Published in Proceedings of the Association for Information Science and Technology, v. 57, issue 1, e212.

Author(s) retain copyright, but ASIS\&T receives an exclusive publication license.

The copyright holders have granted the permission for posting the article here. 


\title{
Values, risks, and power influencing librarians' decisions to host drag queen storytime
}

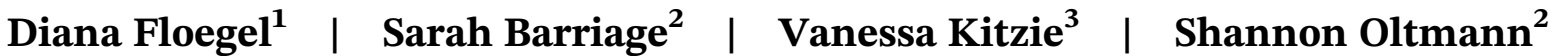

\begin{abstract}
${ }^{1}$ Rutgers School of Communication and Information, Department of Library and Information Science, New Brunswick, New Jersey

${ }^{2}$ University of Kentucky, College of Communication and Information, School of Information Science, Lexington, Kentucky

${ }^{3}$ University of South Carolina, College of Information and Communications, School of Information Science, Columbia, South Carolina
\end{abstract}

\section{Correspondence}

Diana Floegel, Rutgers School of Communication and Information, 4 Huntington St, New Brunswick, NJ 08901. Email: djf185@scarletmail.rutgers.edu

\begin{abstract}
This paper reports preliminary qualitative findings from a survey of public library staff who work at libraries that have and have not hosted drag queen storytimes (DQS), a popular but contested children's program. Three constructs-values, risks, and power-are developed to describe how individual, library, and institutional forces combine to determine whether DQS occur. Findings contribute to limited scholarly work on DQS by including locations that have not hosted DQS and by engaging critically with how institutional forces shape library staffs' decision-making around DQS. It is critical to understand factors contributing to this decision-making to inform contextually appropriate strategies for encouraging dialogue about DQS as well as LGBTQ+ visibility and justice in children's programming. Moreover, DQS constitute a salient context through which to critically explore broader issues of power and inclusion in public libraries.
\end{abstract}

\section{1 | INTRODUCTION}

Drag queen storytimes (DQS) are programs where drag performers lead storytimes in libraries and other venues that focus on children and literacy. DQS attract attention due to extreme levels of support and opposition within community and national contexts. Professional and developing scholarly literature discuss arguments for and against DQS (Pereira, 2019; Pierpoint, 2019), as well as librarians' experiences hosting DQS (Condren, 2018; Landgraf, 2018; Naidoo, 2018) and the benefits of DQS for communities (Montague \& Latham, 2019). However, such literature has yet to consider DQS within the context of power and inequities in libraries. This is a significant gap given that responses to DQS are often tied to values related to LGBTQ+ visibility and acceptance (Bui, 2018).

Literature notes that libraries' relationships with LGBTQ+ communities are fraught. While some institutions have a history of outreach to LGBTQ+ youth
(Oltmann, 2015), LGBTQ+ people have inconsistent experiences in libraries given spatial, service, discursive, and resource inequities (e.g., Floegel, 2019; Wagner \& Crowley, 2020). Such inequities stem from normative values that are instantiated in the library ethos, including structural whiteness, cis/heteronormativity, and an epistemic of neutrality (e.g., Drabinski, 2013; Gibson et al., 2017).

DQS provides a salient context through which to contribute to literature on libraries' relationships with LBGTQ+ communities, particularly because literature to date largely does not include in-depth explorations of library programming, especially children's programming. In order to begin to critically examine DQS in light of power and inequities in libraries, we present preliminary qualitative findings from a survey of public library staff. We investigate how their decisions to host or not host DQS relate to institutional bodies and institutionalized discourses that intersect with libraries as a phenomenon of interest. 


\section{2 | METHODS}

We developed a Qualtrics survey to investigate public library staff members' perceptions of and experiences with DQS. Respondents include those who have and have not hosted DQS. We randomly sampled three libraries from each US state, contacting their children's librarians or library directors, and identified US-based professional and institutional listservs to disseminate our email recruitment message. Four hundred and fifty-eight people responded to the survey from August to September 2019.

This paper reports on a portion of short-answer questions that concern institutional responses to DQS. Questions solicited respondents' perceptions of how library administration, religious organizations, and local governments feel about DQS, as well as how such bodies shape whether survey respondents host DQS. Questions also solicited respondents' perspectives about DQS. The first author analyzed data using interpretivist inductive methods; they used the constant comparative method to conduct rounds of open, axial, and focused coding to develop codes, categories, and constructs from the data (Charmaz, 2014). They engaged in extensive memoing and peer debriefing with the other authors to strengthen findings' trustworthiness (Lincoln \& Guba, 1985). Three constructs were developed during data analysis: values, risks, and power.

\section{3 | RESULTS}

Values, risks, and power manifest on individual, library, and institutional levels (see Table 1). They are interrelated; for example, a person's values may influence whether they perceive DQS to pose risks to attendees, but their perspective may be irrelevant if they lack the power to control library programming.

\section{1 | Values}

Values describe ideologies that inform decision-making. On an individual level, values include library staff members' personal perceptions of LGBTQ+ people and drag. One librarian anticipates that her library will not host DQS in the future because "none of the staff involved in youth event planning are passionate about LGBT+ affirming family events." Conversely, a library director who hosted DQS notes: "We have staff members who are hugely supportive!”

At the library level, values encompass a library's strategic plan, mission, and desire to remain neutral. One librarian thinks her library will host a DQS because "there is strong advocacy for equity and inclusion
T A B L E 1 Constructs, categories, and codes developed during data analysis

\begin{tabular}{|c|c|c|}
\hline Constructs & Categories & Codes \\
\hline \multirow[t]{3}{*}{ Values } & Individual & $\begin{array}{l}\text { Perceptions of LGBTQ+ } \\
\text { populations and materials }\end{array}$ \\
\hline & Library & $\begin{array}{l}\text { Strategic plan; mission; } \\
\text { maintaining neutrality }\end{array}$ \\
\hline & Institutional & Religion; politics \\
\hline \multirow[t]{3}{*}{ Risks } & Individual & Safety; childhood development \\
\hline & Library & Reputation; fiscal constraints \\
\hline & Institutional & Insider/outsider dynamics \\
\hline \multirow[t]{3}{*}{ Power } & Individual & Privilege; financial resources \\
\hline & Library & Hierarchical positions \\
\hline & Institutional & Voice; funding \\
\hline
\end{tabular}

programs...to support our current strategic planning process." However, a branch manager claims, "[DQS] do not fit with our strategic plan or mission."

Some respondents oppose DQS because they claim it conflicts with library policies that should be neutral. Library staff share concerns that DQS "[pushes] a particular social agenda on our patrons" or "could be viewed as the library stepping out of bounds." One librarian believes that DQS "represents a non-neutral political stance on a hot-button issue....and the library profession does itself a disservice by so overwhelmingly getting on board with this trend."

On an institutional level, values coalesce around religious and political orientations. Respondents describe religious organizations that oppose DQS; members may "call and complain," express negative opinions online, or protest at events. Such opposition is not universal; some respondents receive support from religious institutions. A librarian recounts:

[W]e met with a few church officials ... and they were so glad we had storytime. They ... said they would back us in the future if other churches tried to step in.

Respondents also describe political values. Those from conservative communities experience more challenges to DQS - or are more concerned about potential challengesthan those who describe their communities as liberal. However, respondents' comments demonstrate that political landscapes are rarely binary; library staff members contend with gradations of conservative and liberal community organizations, and most encounter both supporters and detractors within them. One librarian's experience illustrates these competing values: her library was "attacked with hateful comments on ... Facebook" but then "people who normally do not participate in writing letters began to 
write in to express their support." Ultimately, the library hosted DQS. As one children's services manager notes, "No community is homogeneous."

\section{2 | Risks}

Risks refer to perceived benefits and drawbacks to hosting DQS. Benefits and drawbacks are not binary concepts, nor are they consistent across librarians' responses. For example, contradictions exist in the data regarding whether having drag performers in the library is a benefit or a risk of DQS programming.

On an individual level, risks include threats to people's safety as well as concerns regarding children's development. A librarian recounts receiving death threats for hosting DQS, while others share concerns about attendees' safety, given protests that occur in response to DQS. A manager explains that if she "would not have to worry about protestors and safety issues for families, I would consider [hosting]." Library staff who describe mitigating safety risks often focus on providing "protections" including increased police presence.

Respondents express heightened concerns because DQS are for children. While some believe that DQS benefit children and communities, others argue that programs risk harming children's development. A librarian claims, "[Drag] is inappropriate for minors and, I think, could be called child abuse to allow a child to participate in a drag event." Though hers is an extreme perspective, another librarian claims that "there are more developmentally appropriate ways to share about these topics."

Library risks pertain to a library's reputation and fiscal constraints. Librarians express concerns about controversies spurred by DQS:

I think it would be divisive and political and I do not want to offend my patrons with this program. I don't think it's worth the hassle.

Many also describe administrators who wish to avoid risks: "Administration has preemptively made it clear that we should not hold programs that are likely to be controversial or politically charged."

DQS poses financial risks for librarians who worry that programs may not be "successful" as defined by metrics like high attendance. A librarian claims: "Using our very limited budget on [DQS] was a gamble." Another staff member notes that "the cost of security" is a problem.

Conversely, respondents claim that DQS may be an opportunity to have "a great photo opp" or demonstrate "progressive" stances and subsequently garner support or attention for a library. An associate says, "Admin ... like to jump in on whatever the latest trend is and prove how inclusive they are."

Institutional-level risks involve broader discussions of who is an "outsider," and therefore risky. Respondents say that performers are outside libraries and outside normative conceptions of storytellers. Due to their outsider status, performers are subject to increased scrutiny or exclusion from library events. While some librarians do not have access to drag performers, those with access debate whether performers are equipped to read to children. A librarian recounts a staff meeting: "While the majority of staff are liberal, everyone expressed concerns with having a drag queen lead a storytime, including would we conduct a background check." Others echo concerns about using "outside" readers, and some worry that library policies forbid them from doing so.

Additionally, some respondents relate DQS to other library services, programs, and materials that center LGBTQ+ people. Librarians list personal and administrative perspectives that frame services, spaces, and collections like "any children's books with LGBTQ+ themes," "LGBTQ+ pride displays," and "allow[ing] teens to put their preferred pronouns on their nametags" as subject to community opposition.

\section{3 | Power}

Power describes an actor's ability to decide whether to host DQS and implement that decision. DQS require support from powerful actors including individuals, library administrators, and other community leaders.

Power may manifest as capital. Privileged individuals can fund DQS to circumvent a library's budget or to avoid accusations that libraries are using taxpayer money to host the event. One head of youth services wrote a "personal check" to fund the event, while another received funding "from [a] city Council member." Conversely, powerful individuals may be able to curtail a library's fiscal efforts to host DQS. One librarian expresses concern that an "authorizing agent" may not approve funding.

Hierarchical organizations of power in libraries ensure that the decision to host DQS does not only lie with librarians; administrators maintain executive authority. One librarian explains: "if the administration got it in their mind to do one, it would almost be guaranteed." Another describes their positive experience with hosting DQS: "library administrators fully had our backs." Conversely, a librarian recalls, "admin shut it down." Administrative power may force librarians who do not support DQS to host them or may prevent librarians who wish to host from doing so. One director 
admits, "If ... I had a convincing argument as to the need for [DQS,] staff, board, and possibly the city government would support me."

On an institutional level, hosting DQS depends on various groups' "voices"; library staff comment that groups with the loudest voices, or greatest influences, affect whether DQS occurs. A librarian recalls, "many people in the community supported the event but the loudest and most persistent community members were opposed." Institutional bodies outside of the library may supersede library administration; respondents claim that local governments influence whether a library hosts DQS. Conflicts may exist between organizations that have a stake in DQS, and these conflicts are often resolved based on which group holds more power. A library director notes that he "got pushback from [the Mayor], but the library is run by the county"; his library was able to host with county officials' support.

Additional institutions with financial means can intervene to support DQS. Grant-giving agencies possess power over whether a library can host DQS, particularly when a library's budget cannot or will not cover the costs. A librarian says they have not hosted DQS because "We applied for a grant and were rejected," while another says, "we would need a grant to help with programming expenses." Local LGBTQ+ organizations may also "[offer] to host free storytimes," while other groups may make "donations to hold DQS" if alternate funding is not available.

\section{4 | DISCUSSION}

Values, risks, and power simultaneously influence whether a library hosts DQS. They demonstrate that individual librarians' beliefs about DQS may become irrelevant in light of library polices and broader institutional forces that influence libraries. Librarians do not typically engage in decision-making alone, and they often do not have exclusive power to determine whether DQS occur in their libraries. Instead, individual, intra-library, and institutional forces combine to determine whether DQS occur, and typically actors with the most power in a particular context exert the greatest influence.

Though DQS describe a specific type of library programming, it provides a context through which scholars and practitioners can think critically about inclusion, exclusion, and power in libraries. Further, librarians' experiences with DQS demonstrate that libraries are not isolated institutions; decisions made in libraries intersect with other institutional bodies such as local governments, as well as institutionalized dynamics including cis/ heteronormativity (Drabinski, 2013), especially as they relate to children's development (Robinson, 2012).

Results suggest that some library staff continue to strive for neutrality, which is fallacious and harmful given that such ideologies propagate oppression; neutrality is an institutionalized ideal that harms marginalized people both in and outside of libraries (Gibson et al., 2017). Results also highlight the complexities surrounding DQS and other efforts toward inclusion in libraries. Librarians admit that motivations to host DQS at least partly stem from the desire to appear inclusive and generate positive press for libraries. This suggests that institutions may engage with a certain level of performativity (Peterson, 2017) when considering DQS.

Further, tension exists between mitigating risks posed by DQS (e.g., bodily harm due to protests) through security measures and creating welcoming or safe spaces in libraries. Given violence committed against LGBTQ+ people and people of color by law enforcement, safety at an event like DQS is not a simple issue but is instead tied to wider institutional dynamics regarding marginalization, inequity, and policing (Browne, 2015).

Results contribute to conversations about insider/outsider dynamics in libraries (Chatman, 1996; Wager \& Crowley, 2020). Responses suggest that libraries continue to perceive LGBTQ+ people and materials as "risks" to their communities and, especially, to children. Respondents frame drag performers as outsiders because of their identities or assumed storytelling skills. However, others who exist outside the library but possess more power, such as people who may fund DQS, are not treated with such suspicion. Because they structurally possess power, their influence is permitted, whereas performers often are less welcome.

Values, risks, and power involved in librarians' decision to host or not host DQS highlight tensions around inclusivity in libraries. These constructs may be further developed to encourage dialogue around DQS in particular, and LGBTQ+ visibility and justice in children's programming more generally.

\section{5 | CONCLUSION}

The study is limited in its sampling; library staff who provided qualitative feedback express particularly strong views about DQS. Survey responses were brief and did not permit opportunities for follow-up. The researchers' ongoing work addresses these limitations through further data collection; interviews are underway with library staff and performers in order to further develop these constructs. 
Findings concerning values, risks, and power contribute to scholarship that investigates inequities in libraries. Findings should encourage dialog that moves beyond "diversity" initiatives and towards just and sustainable institutional changes in libraries. Future work should continue to develop these constructs as they relate to DQS and as they are transferable to other decisionmaking processes in libraries and other institutions.

\section{REFERENCES}

Browne, S. (2015). Dark matters: On the surveillance of blackness. Durham, NC: Duke University Press.

Bui, C. (2018, August 21). Community split over New Jersey library's 'drag queen story hour' for children. CBS New York. Retrieved from https://newyork.cbslocal.com/2018/08/21/rahwaydrag-queen-story-hour/

Charmaz, K. (2014). Constructing grounded theory (2nd ed.). Thousand Oaks, CA: Sage.

Chatman, E. A. (1996). The impoverished life-world of outsiders. Journal of the American Society for Information Science, 47(3), 193-206.

Condren, C. (2018). Far from a drag: How one library embraced Drag Queen Story Hour. Children \& Libraries, 16(1), 21-22.

Drabinski, E. (2013). Queering the catalog: Queer theory and the politics of correction. The Library Quarterly, 83(2), 94-111.

Floegel, D. (2019). "A good intention gone awry": Queering makerspaces to support queer creators. Proceedings of the 82nd Annual Meeting of ASIS\&T, Melbourne, Australia, October 19-23, 2019.

Gibson, A. N., Chancellor, R. L., Cooke, N. A., Dahlen, S. P., Lee, S. A., \& Shorish, Y. (2017). Libraries on the frontlines: Neutrality and social justice. Equality, Diversity and Inclusion, 36(8), 751-766.

Landgraf, G. (2018, November 1). Fierceness - and fierce opposition. American Libraries. Retrieved from https://americanlibraries magazine.org/2018/11/01/drag-queen-storytimes-fierceness-fier ce-opposition/
Lincoln, Y. S., \& Guba, E. G. (1985). Naturalistic inquiry. Beverley Hills, CA: Sage.

Montague, R.A., \& Latham, J. (2019). Queer reflections: New views from library drag storytimes. Paper presented at IFLA World Library and Information Congress. Athens, Greece, August 24-30.

Naidoo, J. C. (2018). A rainbow of creativity: Exploring drag queen storytimes and gender creative programming in public libraries. Children \& Libraries, 16(4), 12-20.

Oltmann, S. M. (2015). Variables related to school media center LGBT collections. Libri, 65(1), 25-33.

Pereira, A. (2019, February 12). After protests, an estimated 500 attend East Bay library's 'drag queen story hour.' SFGate. Retrieved from https://www.sfgate.com/local/article/dragqueen-story-hour-brentwood-library-east-bay-13611760.php

Peterson, E. (2017). On allyship and performative wokeness. Medium. Retrieved from https://medium.com/@Tawdry_ Hepburn/on-allyship-and-performative-wokeness-30581808bf8b

Pierpoint, G. (2019, February 20). Drag queen story hour in America's Bible belt. $B B C$ News. Retrieved from https://www.bbc. com/news/world-us-canada-47203976

Robinson, K. H. (2012). "Difficult citizenship": The precarious relationships between childhood, sexuality and access to knowledge. Sexualities, 15(3-4), 257-276.

Wager, T. L., \& Crowley, A. (2020). Why are bathrooms inclusive if the stacks exclude?: Systemic exclusion of trans and gender nonconforming persons in post-trump academic librarianship. Reference Services Review, 48, 159-181. https://doi.org/10.1108/ RSR-10-2019-0072

How to cite this article: Floegel D, Barriage $S$, Kitzie V, Oltmann S. Values, risks, and power influencing librarians' decisions to host drag queen storytime. Proc Assoc Inf Sci Technol. 2020;57:e212. https://doi.org/10.1002/pra2.212 